\title{
Temporal and hormonal regulation of inhibin protein and subunit mRNA expression by post-natal and immature rat ovaries
}

\author{
A E Drummond, M Dyson, E Thean, N P Groome ${ }^{1}$, \\ D M Robertson and J K Findlay
}

Prince Henry's Institute of Medical Research, PO Box 5152, Clayton, Victoria 3168, Australia

${ }^{1}$ Oxford Brookes University, Oxford OX3 OBP, UK

(Requests for offprints should be addressed to A E Drummond; Email: ann.drummond@med.monash.edu.au)

\begin{abstract}
The contribution of specific follicle populations to dimeric inhibin production and inhibin subunit mRNA expression by the rat ovary has been investigated in two model systems, granulosa cells isolated from 25-day-old diethylstilboestrol (DES)-treated rats and post-natal rat ovaries, dispersed in culture or whole ovaries, using specific two-site immunoassays and 'real time' PCR. Media from FSH-stimulated granulosa cell cultures fractionated by gel filtration and RP-high performance liquid chromatography revealed two predominant peaks of $\alpha$ subunit activity which were attributed to $\alpha$ subunit and $31 \mathrm{k}$ dimeric inhibin-A. The corresponding inhibin-B levels were low. FSH stimulation did not alter the ratio of inhibin-A: $\alpha$ subunit produced by granulosa cells. All three inhibin subunit mRNAs were expressed by granulosa cells, with eight-fold more $\alpha$ subunit mRNA relative to either of the $\beta$ subunits. Administration of DES to immature rats prior to the isolation of granulosa cells from the ovary led to $\beta_{\mathrm{A}}$ and $\beta_{\mathrm{B}}$ mRNA expression being down-regulated in the absence of any significant change in $\alpha$ subunit expression by the granulosa cells.

Inhibin- $A,-B$ and $-\alpha$ subunit were produced by basal and stimulated cultures of ovarian cells prepared from 4-, 8 - and 12-day-old rats, indicating that primary, preantral and antral follicles contribute to total inhibin production. Consistent with these results, follicles within these ovaries expressed all three inhibin subunit mRNAs, with maximal expression observed in the ovaries of 8-day-old rats. The appearance of antral follicles in the ovary at day 12 led to a decline in the mRNA levels of each of the subunits but
\end{abstract}

was most evident for the $\beta$ subunits. There was a profound influence of secondary preantral follicles on dimeric inhibin-A production, with FSH stimulation increasing inhibin-A relative to $\alpha$ subunit levels in cultures of ovarian cells prepared from 8-day-old rats. Thus, preantral follicles exposed to FSH contribute significantly to $\beta_{\mathrm{A}}$ subunit production by the ovary. In contrast, primary and preantral follicles did not produce inhibin-B in response to FSH stimulation. Transforming growth factor- $\beta$ (TGF- $\beta$ ) enhanced, in a time-dependent manner, the production of the inhibin forms by ovarian cells in culture, although inhibin-B production was not responsive until day 8 . The simultaneous treatment of ovarian cell cultures with FSH and TGF- $\beta$ elicited the greatest increases in production of all the inhibin forms.

In summary, ovaries of 4-, 8- and 12-day-old rats expressed inhibin subunit mRNAs and produced dimeric inhibin-A and $-\mathrm{B}$ and free $\alpha$ subunit. Preantral follicles (day-8 ovarian cell cultures) were particularly sensitive to stimulation by FSH and TGF- $\beta$ and had a substantial capacity for inhibin production. The production of oestrogen by follicles may be instrumental in regulating inhibin production given that $\beta$ subunit mRNA expression was down-regulated by DES. The mechanisms by which inhibin-A and inhibin-B are individually regulated are likely to be similar during the post-natal period, when folliculogenesis is being established, and diverge thereafter, when inhibin-A becomes the predominant form in the fully differentiated ovary.

Journal of Endocrinology (2000) 166, 339-354

\section{Introduction}

Inhibin, a heterodimeric molecule composed of an $\alpha$ and $\beta$ subunit linked by disulphide bonds, is produced by granulosa cells of the ovary and feeds back on the pituitary to negatively regulate follicle-stimulating hormone (FSH) secretion (for reviews see McLachlan et al. 1987, Burger
1993). Inhibin is also thought to play local regulatory roles in the ovary since it has been shown to directly modulate thecal cell androgen synthesis (Hillier et al. 1991) and oestrogen production (Smyth et al. 1994), and it has been postulated to promote follicular growth (Woodruff et al. 1990). Recently, binding sites for inhibin were demonstrated on ovarian cells (Draper et al. 1998). 
Two forms of dimeric inhibin have been identified on the basis of the contributing $\beta$ subunit, either $\beta_{\mathrm{A}}$ which gives rise to inhibin- $\mathrm{A}$, or $\beta_{\mathrm{B}}$ which gives rise to inhibin-B. It has been shown previously by Northern blot, in situ hybridisation and immunohistochemical analyses (Woodruff et al. 1987, 1988, Meunier et al. 1988, Jih et al. 1993, Drummond et al. 1996) that mRNA and protein, respectively, for the inhibin subunits $\left(\alpha, \beta_{\mathrm{A}}\right.$ and $\left.\beta_{\mathrm{B}}\right)$ are produced by ovarian granulosa cells, and inhibin immunoactivity and bioactivity have been measured in ovarian extracts and conditioned media collected from granulosa cell and ovarian cell cultures (Erickson \& Hsueh 1978, Bicsak et al. 1986, Suzuki et al. 1987, Robertson et al. 1988, Drummond et al. 1996). It is still unclear, however, which of the biologically active forms produced by the ovary are responsible for the actions of inhibin and whether the production of the inhibin forms varies according to the stage of ovarian development or follicle type. Studies of human plasma and follicular fluid indicate that inhibin-B is likely to be the predominant form in the early follicular phase of the menstrual cycle when small antral follicles are recruited, but that inhibin-B levels subside during the late follicular phase as inhibin-A levels ascend with the appearance of the dominant follicle and peak after ovulation (Groome et al. 1996). Follicular fluid aspirated from early follicular-phase follicles contains inhibin-B at concentrations up to 200-fold higher than inhibin-A (Groome et al. 1996, Magoffin \& Jakimiuk 1997). In cycling female rats, serum profiles of inhibin-A and $-\mathrm{B}$ are similar (Woodruff et al. 1996), although inhibin-B levels were higher than inhibin-A during metoestrus which may reflect changes in the follicle population and recruitment of new follicles into the next cycle.

Our interest in the ovary has focused on the early stages of folliculogenesis and, in particular, the period of development when follicle populations are established for the first time. We have defined these stages in the post-natal rat ovary and characterised the specific follicle populations present 4, 8 and 12 days after birth (Drummond et al. 1996). Follicle populations from primordial and primary (day 4) to preantral (day 8) to antral (day 12) appear in the ovary in a sequential manner so that it is possible to examine, in isolation, specific follicle populations. Thus, this model provides a unique opportunity to examine the role of primordial and primary, preantral/secondary and antral follicles in inhibin production.

In recent years, inhibin has been measured in biological fluids by either in vitro bioassay or radioimmunoassay (RIA). The lack of assay specificity and the detection of immunoactivity in samples which conferred little or no biological activity has impeded the elucidation of roles for the individual inhibin forms in the regulation of ovarian function and FSH secretion. With the availability of 'two-site' assays for the specific inhibin forms (Groome 1991, Groome et al. 1996, Robertson et al. 1997) it is now possible to begin addressing these issues.
We previously examined the role of activin in the post-natal ovary and demonstrated a facilitatory action of activin in mediating the responsiveness of granulosa cells to FSH in terms of progesterone and inhibin production (Drummond et al. 1996). Apart from activin, other members of the transforming growth factor- $\beta$ (TGF- $\beta$ ) family of peptides, notably TGF- $\beta$, have been shown to locally regulate aspects of ovarian function (Knecht et al. 1987, Zhang et al. 1988, Dunkel et al. 1994, Lanuza et al. 1999). TGF- $\beta$ stimulated inhibin production by isolated granulosa cells (Zhang et al. 1988, Lanuza et al. 1999), with the suggestion that inhibin-B may be stimulated in preference to inhibin-A (Lanuza et al. 1999). The potential for TGF- $\beta$ and activin to initiate different responses within ovaries, depending on the age of the donor animal and follicular status or, alternatively, issues related to redundancy if similar roles exist, remain to be clarified. These studies were undertaken to measure the hormonal (TGF- $\beta$, FSH) and temporal regulation of inhibin-A, inhibin-B and inhibin- $\alpha$ subunit produced by post-natal rat ovarian cells. In addition, the inhibin forms produced by the immature ovary were investigated using granulosa cell-conditioned media prepared from diethylstilboestrol (DES)-treated rats. Inhibin-B and inhibin- $\alpha$ subunit were measured using established assays (Groome et al. 1996, Robertson et al. 1997) whereas a new, previously unpublished immunofluorometric assay (IFMA) was used to measure inhibin-A.

Since we cannot directly compare the levels of inhibin-A, $-\mathrm{B}$ and $-\alpha$ subunit due to the absence of a suitable rat standard, we decided to quantitate the steadystate mRNA levels of the inhibin subunits in the ovary during post-natal development and in isolated granulosa cell preparations using novel 'real time' polymerase chain reaction (PCR) technology. Changes in the expression of the inhibin subunit mRNAs by specific follicle populations and the impact of in vivo oestrogen treatment prior to granulosa cell isolation in a well-characterised immature rat model were investigated.

\section{Materials and Methods}

\section{Hormones and reagents}

Rat FSH (rFSH-I8) was obtained from the National Hormone and Pituitary Distribution Program and the NIADDK, NIH (Baltimore, MD, USA). Human recombinant-activin A was provided by Dr A Mason (Biota, Clayton, Victoria, Australia). Natural human TGF- $\beta$ was purchased from Genzyme (Cambridge, MA, USA). Human recombinant inhibin-B was provided by Dr J Mather (Genentech Inc., South San Francisco, CA, USA). Human recombinant inhibin-A was provided by Biotech Australia (Roseville, NSW, Australia). 
Animals

Sprague-Dawley rats were obtained from Central Animal Services, Monash University (Melbourne, Australia). The project was approved by the institutional Animal Experimentation and Ethics Committee as conforming to the guidelines of the National Health and Medical Research Council of Australia.

\section{Post-natal ovarian cell cultures}

Dispersed ovarian cell suspensions were prepared by enzymatic digestion (Drummond et al. 1996) from 4-, 8and 12-day-old rats. Briefly, cells $\left(1.5 \times 10^{5} /\right.$ well $)$ were incubated in quadruplicate in serum-free McCoy's $5 \mathrm{C}, \mathrm{C}$ McCoys SA (Trace Biosciences, Sydney, Australia) containing transferin and glutamine alone or with FSH $(20 \mathrm{ng} / \mathrm{ml})$, TGF- $\beta(10 \mathrm{ng} / \mathrm{ml})$ or a combination of FSH plus TGF- $\beta$, at the doses indicated for single treatments alone. The doses of TGF- $\beta$ and FSH were chosen based on their ability to stimulate immunoactive inhibin production (A E Drummond, M Dyson \& J K Findley 1996, unpublished observations). To investigate the time-course of inhibin production, cells were incubated for $6,12,24$, 48 or $72 \mathrm{~h}$, after which the conditioned media were collected and stored frozen until required for assay. Other ovarian cell cultures were incubated in McCoy's $5 \mathrm{C}$ with treatments for $48 \mathrm{~h}$ at $37^{\circ} \mathrm{C}$. Individual wells of cultures were pooled ( $n=10-15$ wells) for characterisation of inhibin immunoactivity by the respective assays. The pools were frozen until required for assay. Under all culture conditions, cell numbers were unchanged, as determined by a neutral red proliferation assay (Lowik et al. 1993).

\section{Granulosa cell cultures}

Granulosa cell cultures were prepared from 25-day-old, DES-treated rats as previously described (Xiao et al. 1990). Briefly, cells $\left(2 \times 10^{5} /\right.$ well $)$ were incubated for $48 \mathrm{~h}$ at $37^{\circ} \mathrm{C}$ in McCoy's $5 \mathrm{C}$ in the presence or absence of FSH $(20 \mathrm{ng} / \mathrm{ml})$. Two conditioned media pools, a basal control pool (CM) and an FSH-stimulated pool (CM-FSH) were prepared, and used in either fractionation studies or as quality controls in the inhibin assays. A marked decrease in the levels of the inhibin forms which could be measured by immunoassay was noted with time, even though the pools were aliquoted and did not undergo repeated cycles of freeze-thawing. This loss of activity was prevented by the following treatment: an aliquot of CM-FSH was concentrated (Centricon; Amicon Inc., Beverly, MA, USA) and then gel filtered (PD10 column; Pharmacia, Uppsala, Sweden) to TSA (50 mM Tris- $\mathrm{HCl} / 0 \cdot 9 \%$ $\left.\mathrm{NaCl} / 0 \cdot 05 \% \mathrm{NaN}_{3}, \mathrm{pH} 7 \cdot 5\right) / 0 \cdot 5 \%$ bovine serum albumin (BSA). Aliquots were snap frozen and stored at $-20{ }^{\circ} \mathrm{C}$ until required.
Gel filtration and reverse phase-high performance liquid chromatography (RP-HPLC)

Conditioned media (CM-FSH) was fractionated by gel filtration and RP-HPLC. Gel filtration of CM-FSH was undertaken using a Superdex HR 75 column (Pharmacia) in $20 \mathrm{mM}$ Tris/ $10 \%$ acetonitrile/ $0 \cdot 2 \mathrm{M} \mathrm{NaCl} / 0 \cdot 05 \%$ BSA, $\mathrm{pH} 7 \cdot 5$. The flow rate was $0.4 \mathrm{ml} / \mathrm{min}$ and $0.2 \mathrm{ml}$ fractions were collected. The fractions were stored frozen until required for assay. Fractionation of CM-FSH by RP-HPLC was undertaken using a $\mathrm{C} 4$ column (Brownlee; Applied Biosystems, San Jose, CA, USA) connected to a Waters HPLC system (Milford, MA, USA). The column was eluted with a linear gradient of $0-50 \%$ acetonitrile in $0 \cdot 1 \%$ trifluoroacetic acid. The flow rate was $1 \mathrm{ml} / \mathrm{min}$ and $0.5 \mathrm{ml}$ fractions were collected. The RP-HPLC fractions were freeze-dried and reconstituted prior to assay in TSA/ $0.5 \%$ BSA.

\section{IFMA for dimeric inhibin- $A$ and inhibin-a subunit}

Buffers and reagents The $\alpha$ subunit antibody used as capture antibody in these assays was raised in sheep against a human recombinant inhibin- $\alpha_{\mathrm{C}}$ subunit fusion protein (Forage et al. 1987, Robertson et al. 1997, 1999). A caprylic acid $\operatorname{IgG}$ cut of sheep antiserum (no. 41) was immunopurified on a column (Reactigel; Pierce, Rockford, IL, USA) coupled to a bovine inhibin- $\alpha_{C}$ subunit fusion protein (provided by Biotech Australia, Roseville, NSW, Australia). The no. 41 antiserum was chosen as capture antibody for the $\alpha$ subunit because of its high affinity for rat inhibins. A monoclonal antibody to the $\beta_{\mathrm{A}}$ subunit (2B10) was raised in mice to a $\beta_{\mathrm{A}}$ subunit fusion protein (provided by Biotech Australia) and screened with human recombinant $31 \mathrm{k}$ inhibin-A. The $2 \mathrm{~B} 10$ antisera was of an $\operatorname{IgG} 2 \mathrm{a}, \kappa$ light chains isotype. The antiserum was purified on a protein $\mathrm{G}$ column. The $2 \mathrm{~B} 10$ antibody binds human $\beta_{\mathrm{A}}$ subunit, human activin-A and human inhibin-A but does not bind human $\alpha_{C}$ subunit, human $\alpha_{N}$ subunit or human inhibin-B. Immunopurified $41 \alpha \mathrm{C}$ and purified 2B10 antisera were biotinylated (Robertson et al. 1997) for use as labelled second antibodies in the appropriate assays. Triton (1\%) was added to the TSA assay buffer to reduce the potential for cross-reaction in the inhibin-A assay with activin. For the $\alpha$ subunit assay, $0 \cdot 1 \%$ ovine $\operatorname{IgG}$ was added to the TSA buffer to prevent heterophilic antibody binding.

Standard preparations Since rat inhibin standards are not available, a human recombinant $31 \mathrm{k}$ inhibin preparation supplied by Biotech Australia (Sydney, Australia) was used in the inhibin-A and inhibin- $\alpha$ subunit assays. Pools of conditioned media collected from rat granulosa cell cultures were tested in the assays for parallelism and linearity to the human standard. The potency of this preparation was calibrated in terms of the WHO human 
$31 \mathrm{k}$ inhibin-A standard 91/624. Relative to the inhibin-A 91/624 preparation, the $31 \mathrm{k}$ human inhibin preparation used as assay standard was 1.1 and 1.2 times more potent in the inhibin-A and $\alpha$ subunit assays respectively.

Assay protocol The assay protocol was similar to that described by Robertson et al. (1997, 1999). Briefly, the capture antibody, 41aC $(1 \mu \mathrm{g} / 200 \mu \mathrm{l})$, was absorbed to wells of 96-well plates (Maxisorp; Nunc, Roskilde, Denmark), during an overnight incubation at $37^{\circ} \mathrm{C}$. The plates were washed twice with wash buffer $(5 \mathrm{mM}$ Tris/ $0 \cdot 9 \% \mathrm{NaCl} / 0 \cdot 05 \%$ Tween $20 / 0 \cdot 05 \%$ merthiolate, $\mathrm{pH}$ 7.75) and then blocked with $1 \%$ BSA in $10 \mathrm{mM}$ phosphate-buffered saline $/ 0 \cdot 9 \% \mathrm{NaCl} / 0 \cdot 1 \% \mathrm{NaN}_{3}$, for a minimum of $2 \mathrm{~h}$ at room temperature (RT). The plates were aspirated and stored at $4{ }^{\circ} \mathrm{C}$ in a humidified atmosphere until required. Samples and standards were diluted in assay buffer or culture media and $100 \mu$ transferred to wells. Media or assay buffer $(100 \mu \mathrm{l} /$ well $)$ was added to bring the total volume to $200 \mu \mathrm{l} /$ well. The plate was then shaken for a minimum of $2 \mathrm{~h}$ at $\mathrm{RT}$ after which it was washed three times, and biotinylated antibody, 2B10 (50 ng/well) for inhibin-A or $41 \alpha \mathrm{C}(100 \mathrm{ng} /$ well $)$ for $\alpha$ subunit, was added to each well and the plate shaken for $2 \mathrm{~h}$ at RT. The plate was then washed three times and the label, Europium-streptavidin (50 ng/200 $\mu \mathrm{l}$; Wallac, Turku, Finland) diluted in assay buffer, was added to each well and the plate shaken for $30 \mathrm{~min}$. After thorough washing, $200 \mu \mathrm{l}$ enhancement solution was added to each well and the plates were shaken for $5 \mathrm{~min}$, after which the fluorescence was measured using time-resolved fluorometry (1234 Fluorometer; Wallac).

The inter- and intra-assay variations for the inhibin-A IFMA were $12 \%$ and $6 \%(n=5)$ respectively, and the sensitivity of the assay was $20 \mathrm{pg} / \mathrm{ml}$. The inter- and intra-assay variations for the $\alpha$ subunit IFMA were 15\% and $5.5 \%(n=3)$ respectively, and the sensitivity of the assay was $100 \mathrm{pg} / \mathrm{ml}$.

\section{Inhibin RIA}

Inhibin forms containing the $\alpha_{\mathrm{C}}$ subunit were also measured using the Monash double antibody RIA described previously (Robertson et al. 1988). The antiserum (no. 1989) was raised against $31 \mathrm{k}$ bovine inhibin and the standard used was a rat ovarian extract of arbitrary unitage (Robertson et al. 1988). The inter- and intra-assay variations were $11.5 \%$ and $<10 \%$ respectively, and the sensitivity of the assay was $0.4 \mathrm{U} / \mathrm{ml}$.

\section{Inhibin-B enzyme-linked immunosorbent assay (ELISA)}

The ELISA method of Groome et al. (1996) was employed. Prior to assay, the samples and standards were boiled in 2\% SDS and treated with hydrogen peroxide, as recommended. A rat ovarian extract (ROVE; Robertson et al. 1988) and a partially purified inhibin-B preparation isolated from human follicular fluid (Groome standard) were used as standards. The Groome standard was used to measure inhibin-B in fractions collected by gel filtration and HPLC. The sensitivity of the assay was $20 \mathrm{pg} / \mathrm{ml}$ (Groome standard). These studies indicated that the human standard preparation was not appropriate for the measurement of rat inhibin-B due to an unacceptably high interassay variation $(32 \%, n=10)$. In order to reduce this variation, the human and ROVE standard preparations were compared in three successive parallel line assays. The potency of the ROVE preparation in terms of the Groome standard was calculated at $1 \cdot 16 \pm 0 \cdot 24 \mathrm{pg} / \mathrm{ml}(n=3)$, with an interassay variation of $36 \%(n=3)$. Parallelism was observed between preparations based on the absence of significant differences in the slope values of the doseresponse lines. The ROVE standard was used in subsequent assays to measure inhibin-B because the inter- and intra-assay variations were acceptable $(10 \% n=3)$. The sensitivity of the assay was $30 \mathrm{U} / \mathrm{ml}$ (ROVE standard).

\section{$R N A$ purification and reverse transcription}

RNA was purified using the method of Chomczynski \& Sacchi (1987) from ovaries of 4-, 8-, 12- and 22-day-old rats (standard and quality control pools) and granulosa cells isolated from the ovaries of 25-day-old rats which were either untreated or treated with DES for 4 days prior to excision of the ovaries (Xiao et al. 1990). The number of ovaries/pool ranged from 24 to 40 for post-natal animals (4- to 12 day-old rats) and 4 to 8 for immature animals (22- to 25-day-old rats). Two micrograms of each RNA/tube were reverse transcribed using Moloney murine leukaemia virus (MMLV) (Expand; Roche, Mannheim, Germany) reverse transcriptase and oligo $\mathrm{dT}_{15}$ (Drummond et al. 1999).

\section{'Real time' PCR analysis of ovarian inhibin subunit $m R N A$ s}

Inhibin subunit mRNA expression was analysed using the Roche LightCycler (Roche). The instrument is a rapid thermal cycler that monitors fluorimetrically, in real time, the formation of PCR products with fluorescent dyes, in this instance SYBR Green I. In its unbound state, SYBR Green I dye has relatively low fluorescence but when bound to double-stranded DNA it fluoresces strongly; thus, as the amount of DNA or PCR product increases, the amount of fluorescence from the dye increases proportionally. The log-linear portion of the amplification curve is identified with the threshold or crossing point (represented in cycle number) defined as the intersection of the best-fit line through the log-linear region and the noise band. In these studies, a rat ovarian cDNA preparation of arbitrary unitage was employed as the assay standard. The levels of expression of each mRNA and their estimated 
Table 1 Oligonucleotide primer sequences for PCR amplification of the rat inhibin subunits and GAPDH cDNAs

\begin{tabular}{|c|c|c|}
\hline & Primer nucleotide sequence & Reference \\
\hline$\alpha$ subunit & $\begin{array}{l}\text { 5'-GCC TTG GCC TTG GTC TCC TGC G-3' (758) } \\
\text { 5'-ACG CGT AGG GAG GTC ATG CTC C-3' (1022) }\end{array}$ & Albano et al. (1993) \\
\hline$\beta A$ subunit & $\begin{array}{l}\text { 5'-TGG AGT GTG ATG GCA AGG TC-3' (1111) } \\
\text { 5'-AGC CAC ACT CCT CCA CAA TC-3' }(1411)\end{array}$ & Woodruff et al. (1987) \\
\hline$\beta B$ subunit & $\begin{array}{l}5^{\prime}-\text { TCT TCA TCG ACT TTC GGC TCA T-3' }(90) \\
5^{\prime}-\text { TGT CAG GCG CAG CCA CAC TCC T-3' }(350)\end{array}$ & Albano et al. (1993) \\
\hline GAPDH & $\begin{array}{l}\text { 5'-GAC CCC TTC ATT GAC CTC AAC-3' (147) } \\
5^{\prime} \text {-GAT GAC CTT GCC CAC AGC CTT-3' (667) }\end{array}$ & Tso et al. (1985) \\
\hline
\end{tabular}

The $3^{\prime}$ nucleotide position of each primer within the published nucleotide sequence is given in parenthesis.

crossing points in each sample were determined relative to the standard preparation using the LightCycler computer software. A ratio of specific mRNA/GAPDH amplification was then calculated. Reagents for reverse transcription and LightCycler PCR were purchased from Roche Biochemicals.

For PCR, $2 \mu \mathrm{l}$ each of the standard cDNA pool diluted 1:5, 1:100 and 1:2000 (arbitrarily designated 1.0, 0.05 and 0.0025 respectively), the quality control cDNA pool diluted 1:25 and the sample cDNAs diluted 1:15-1:25 in sterile water were added to individual capillaries. NTPs, Taq enzyme, reaction buffer and SYBR Green I dye were supplied in the LightCycler DNA Master SYBR Green I kit, of which $2 \mu \mathrm{l} /$ capillary was added. Primer concentrations of $17.5 \mathrm{pmol}$ (GAPDH) and $25 \mathrm{pmol}$ (inhibin subunits) were added to each capillary. The primer specific nucleotide locations and sequences are shown in Table 1. Magnesium concentrations, annealing temperatures and extension times for the individual primer sets are shown in Table 2 . The capillary volume was made up to $20 \mu \mathrm{l}$ with sterile water. Forty cycles of PCR were programmed to ensure that the threshold crossing point (cycle number) was attained. Fluorescence emission was monitored continuously during cycling. At the completion of cycling, melting curve analysis was carried out to establish the specificity of the DNA products produced. In the initial optimisation stages for each primer set, agarose gel electrophoresis, as previously described (Drummond

Table 2 Primer-specific LightCycler conditions and expected product sizes for the inhibin subunit mRNAs and GAPDH

\begin{tabular}{|c|c|c|c|c|}
\hline & $\begin{array}{l}\text { Annealing } \\
\text { temperature }\left({ }^{\circ} \mathrm{C}\right)\end{array}$ & $\begin{array}{l}\mathbf{M g} \\
(\mathrm{mM})\end{array}$ & $\begin{array}{l}\text { Extension } \\
\text { time }(\mathrm{s})\end{array}$ & $\begin{array}{l}\text { Product } \\
\text { size }(b p)\end{array}$ \\
\hline \multicolumn{5}{|l|}{ Primer set } \\
\hline$\alpha$ & 55 & 3 & 14 & 306 \\
\hline$\beta A$ & 60 & 3 & 16 & 338 \\
\hline$\beta B$ & 55 & 4 & 14 & 304 \\
\hline GAPDH & 60 & 3 & 26 & 560 \\
\hline
\end{tabular}

www.endocrinology.org et al. 1999), was also employed to establish the integrity of the PCR reaction and product size.

In most instances, individual pools for each age group or treatment with each primer set were performed in a single PCR experiment. The intra-assay variation was never more than $5 \%(n=7)$ regardless of the primer set. The nature of LightCycler PCR diminishes issues such as assay sensitivity and, at the concentrations (dilutions) of standard and sample utilised in these studies, the sensitivity threshold (picograms) was never approached.

\section{Statistical analysis}

The data from ovarian cell cultures are presented as the mean \pm S.E.M. of determinations from three or four replicate wells (unless specified) within each treatment group, from a single experiment (unless otherwise stated). Each experiment was repeated at least three times. The mRNA expression data are represented as the mean \pm S.E.M. of at least three individual pools of RNA for each age or treatment group, analysed by real time PCR. Statistical significance was determined by analysis of variance after $\log$ transformation of the data and calculation of least significant differences. $P$ values of $<0 \cdot 05$ were regarded as statistically significant. To validate the assays for measurement of rat inhibins, sample and standard dilution curves were assessed by parallel-line bioassay statistics (after log transformation of the data), in order to obtain potency estimates and establish the linearity, parallelism and precision of the dose-response curves (Finney 1964).

\section{Results}

Characterisation of the assays (inhibin- $A$, a subunit IFMAs and inhibin-B ELISA)

Pools of conditioned media collected from basal (CM) and FSH-stimulated (CM-FSH) rat granulosa cell cultures diluted linearly and in parallel to the human $31 \mathrm{k}$ inhibin 
preparation used as standard in the $\alpha$ subunit and inhibin-A IFMAs (Fig. 1). In both CM and CM-FSH pools there was approximately $3 \cdot 5$-fold more $\alpha$ subunit than inhibin-A. The relative levels of inhibin-A: $\alpha$ subunit did not change with FSH stimulation (Table 3). In the inhibin-A IFMA, no significant cross-reaction was observed with human activin-A $(<0.005 \%)$, human inhibin-B (<0.01\%) or human TGF- $\beta(0 \cdot 01 \%)$. Similarly, in the $\alpha$ subunit IFMA, no significant cross-reaction was observed with human activin-A $(0 \cdot 008 \%)$ or human TGF- $\beta$ (0.027\%), but human inhibin-B cross-reactivity was estimated at 93\%. Groome inhibin-B standard and ROVE diluted linearly and in parallel to each other in the inhibin-B ELISA (Fig. 1).

\section{Fractionation of granulosa cell-conditioned media}

Two peaks of $\alpha$ subunit activity were observed following gel filtration of CM-FSH (Fig. 2). The major peak coincided with inhibin-A activity from both the conditioned media pool (CM-FSH) and a media preparation spiked with the $31 \mathrm{k}$ human inhibin-A standard. The smaller peak most likely represents higher molecular weight forms of the free $\alpha$ subunit. Regression analysis of the $\alpha$ subunit and inhibin-A IFMA profiles for the CM-FSH pool revealed a close correlation $(r=0 \cdot 98)$. Low levels of inhibin-B $(<125 \mathrm{pg} / \mathrm{ml})$ were measured across the profile although no distinct elution pattern was observed. To differentiate between $\alpha$ subunit and inhibin-A, CM-FSH was subject to RP-HPLC (Fig. 3). Two broad peaks of $\alpha$ subunit activity were observed. The first peak correlated with inhibin-A activity and represented $52 \%$ of total $\alpha$ subunit activity. It is worth noting that both the inhibin-A and $\alpha$ subunit IFMAs measured similar levels of activity in these fractions. The second peak of activity corresponds to other $\alpha$ subunit-containing inhibin forms. Low levels of inhibin-B $(<150 \mathrm{pg} / \mathrm{ml})$ were measured across a broad area of the profile.

Time-course of inhibin production by dispersed ovarian cell cultures

The time-course of inhibin production by post-natal ovarian cells prepared from 8-day-old rats, under basal or stimulated conditions, as measured by the Monash RIA, inhibin-A and $\alpha$ subunit IFMAs is shown in Fig. 4. Low levels of the inhibin forms were measured at 6 and $12 \mathrm{~h}$, under all treatment conditions. Thereafter, inhibin production by these cultures increased for at least $72 \mathrm{~h}$. The FSH plus TGF- $\beta$ treatment was most effective at stimulating inhibin-A and $\alpha$ subunit production. Similar time-courses were established for ovarian cell cultures prepared from 4- and 12-day-old rats (data not shown).
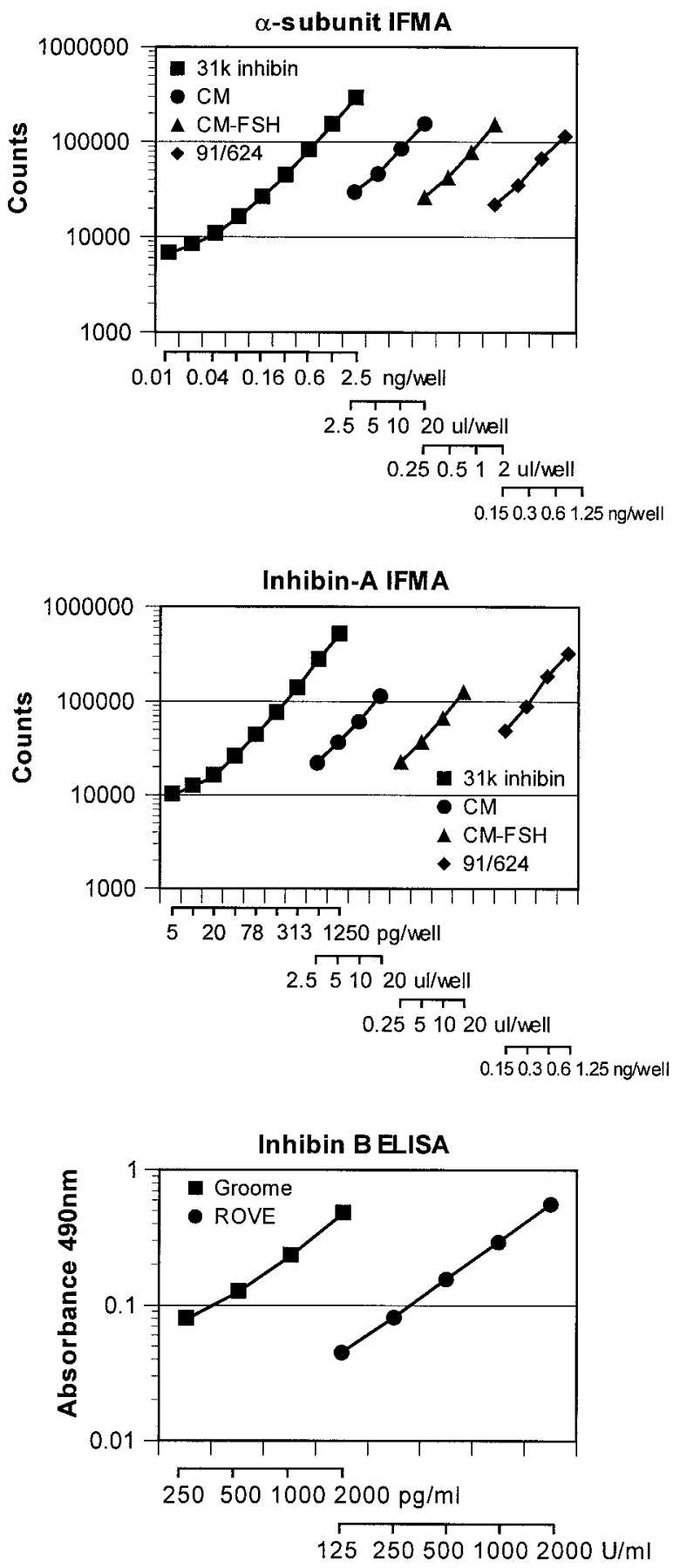

Figure 1 Dose-response curves of standards and conditioned media samples in the inhibin-A and $\alpha$ subunit IFMAs and inhibin-B ELISA. The $31 \mathrm{k}$ inhibin standard, 91/624 inhibin-A standard and conditioned media from basal (CM) and FSH (CM-FSH)-treated rat granulosa cell cultures diluted in parallel with the standard preparation in both inhibin-A and $\alpha$ subunit IFMAs as indicated by the slopes of the regression lines. The intra-assay variation, assessed from the index of precision $(\lambda)$, was 0.033 and 0.019 in $\alpha$ subunit and inhibin-A IFMAs respectively. Groome and ROVE preparations diluted in parallel in the inhibin-B ELISA with the assay $\lambda$ of $0 \cdot 017$. 
Table 3 Levels of inhibin-A and inhibin $\alpha$ subunit in basal (CM) and $\mathrm{FSH}$-stimulated (CM-FSH) conditioned media pools prepared from granulosa cells of DES-treated immature rats

\begin{tabular}{|c|c|c|c|}
\hline & \multicolumn{2}{|c|}{ Activity (ng/ml) } & \multirow{2}{*}{$\begin{array}{l}\text { Inhibin-A/ } \alpha \text { subuni } \\
\text { ratio }\end{array}$} \\
\hline & Inhibin-A & $\alpha$ subunit $^{a}$ & \\
\hline $\mathrm{CM}$ & $18 \cdot 5$ & $70 \cdot 7$ & $0 \cdot 26$ \\
\hline $\mathrm{CM}-\mathrm{FSH}$ & 198 & 645 & $0 \cdot 31$ \\
\hline
\end{tabular}

aAll inhibin forms containing an $\alpha$ subunit will be included in this measurement, e.g. inhibin- $A$, $-B$, free $\alpha$ subunit.

The effect of TGF- $\beta, F S H$ and combined treatments on inhibin- $A$, a subunit and inhibin-B production by ovarian cell cultures

Inhibin-A and $\alpha$ subunit production by dispersed ovarian cell cultures (day-4, -8 and -12 cultures) were stimulated by FSH, TGF- $\beta$ and TGF- $\beta$ plus FSH (Fig. 5). Basal and stimulated levels of inhibin-A and $\alpha$ subunit increased with the age of the donor rat. Inhibin-A, but not $\alpha$ subunit, production by FSH-stimulated day-4 cells was enhanced by TGF- $\beta$. In cultures of ovarian cells prepared from 8 - and 12-day-old rats, TGF- $\beta$ enhanced FSHstimulated inhibin-A and $\alpha$ subunit production (Fig. 5).

Inhibin-B was detected in conditioned medium of all basal cultures of day-4, -8 and -12 ovarian cells (Fig. 5). Inhibin-B production by day-4 ovarian cells was not responsive to FSH or TGF- $\beta$ alone but, in combination, the levels were enhanced approximately $2 \cdot 5$-fold (Fig. 5 ). Day- 8 ovarian cell inhibin-B production remained unresponsive to FSH stimulation although these cells increased their output in response to TGF- $\beta$. In day-12 ovarian cell cultures the response to TGF- $\beta$ alone was greater than the response to FSH alone (Fig. 5). The TGF- $\beta /$ FSH treatment was the most effective at stimulating inhibin-B production by day- 8 and -12 ovarian cells.

To gauge the impact of follicle populations on inhibin-A and $\alpha$ subunit production, the data in Fig. 5 have been replotted as a function of age (Fig. 6). The ratios confirmed the data (Figs 2 and 3) that $\alpha$ subunit is produced in excess of inhibin-A. Preantral follicles of 8-day-old rat ovaries produced considerably more inhibin-A relative to $\alpha$ subunit in response to FSH or TGF- $\beta$ plus FSH, with the ratios similar to those calculated for conditioned media collected from granulosa cell cultures (Fig. 6). In contrast, TGF- $\beta$ alone produced a ratio similar to that observed in control post-natal rat ovarian cultures. The appearance of antral follicles in 12-day-old rat ovaries resulted in an increase in $\alpha$ subunit production relative to inhibin-A, as indicated by a fall in the inhibin-A: $\alpha$ subunit ratio.

\section{Expression of inhibin subunit $m R N A$ s by post-natal ovaries}

Data generated by LightCycler PCR for the inhibin $\alpha$ subunit are represented in Fig. 7. Figure 7A shows the
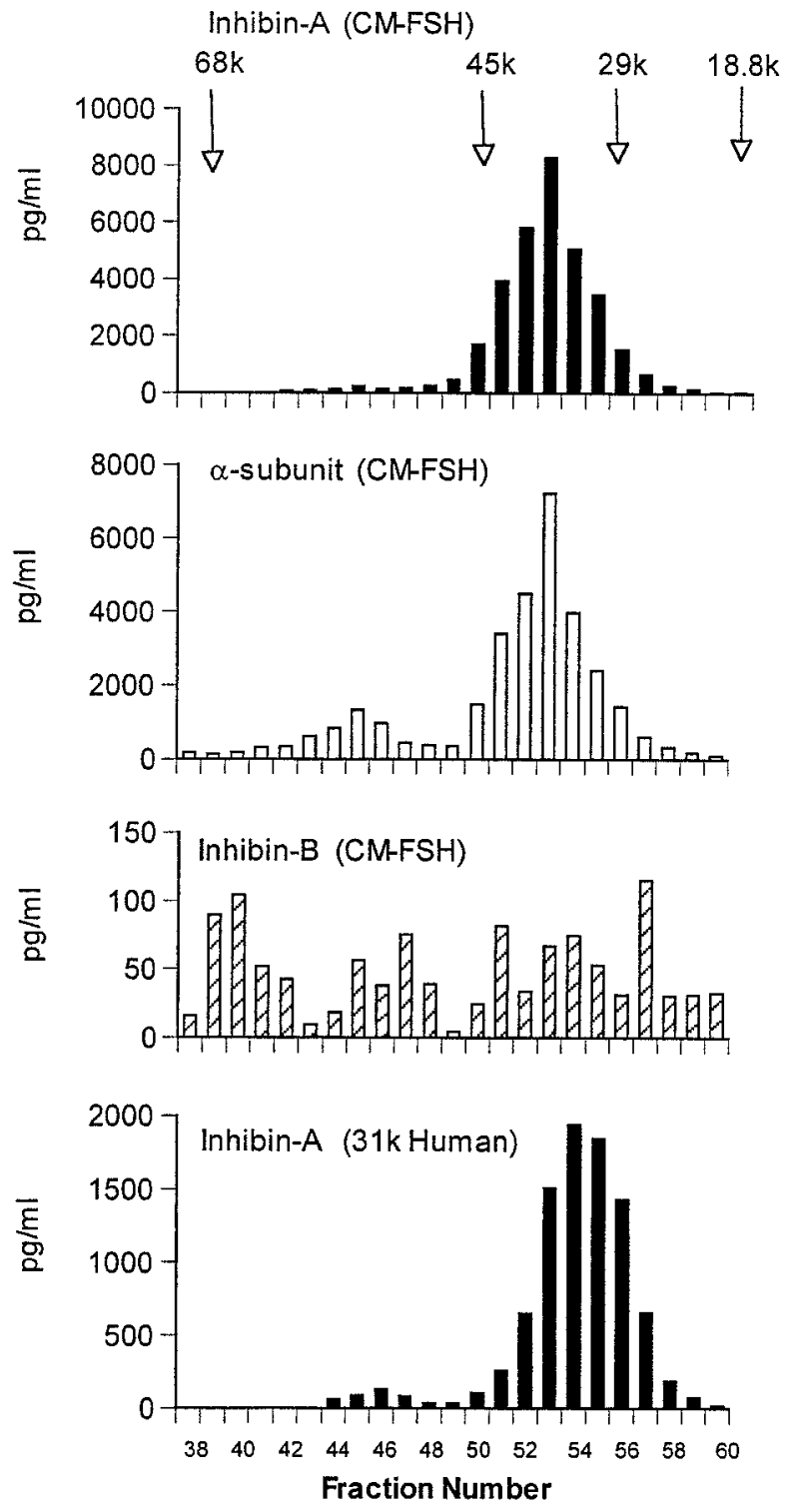

Figure 2 Inhibin gel filtration profiles of conditioned media (CM-FSH) collected from FSH-stimulated granulosa cell cultures and a media preparation spiked with the $31 \mathrm{k}$ human inhibin-A standard. Inhibin-A and $\alpha$ subunit were measured by IFMA and inhibin-B by ELISA (Groome standard preparation) as described in Materials and Methods. Molecular weights of the protein standards and their elution position are indicated: BSA (68 k), ovalbumin (45 k), carbonic anhydrase (29 k) and myoglobin $(18 \cdot 8 \mathrm{k})$.

change in fluorescence of three dilutions of the standard cDNA preparation with increasing cycle number, as a result of amplification of the cDNA. The intersection of the crossing point line, defined after background noise is eliminated from the profile, with the extrapolated $\log -$ linear portion of the fluorescence profile is termed a 

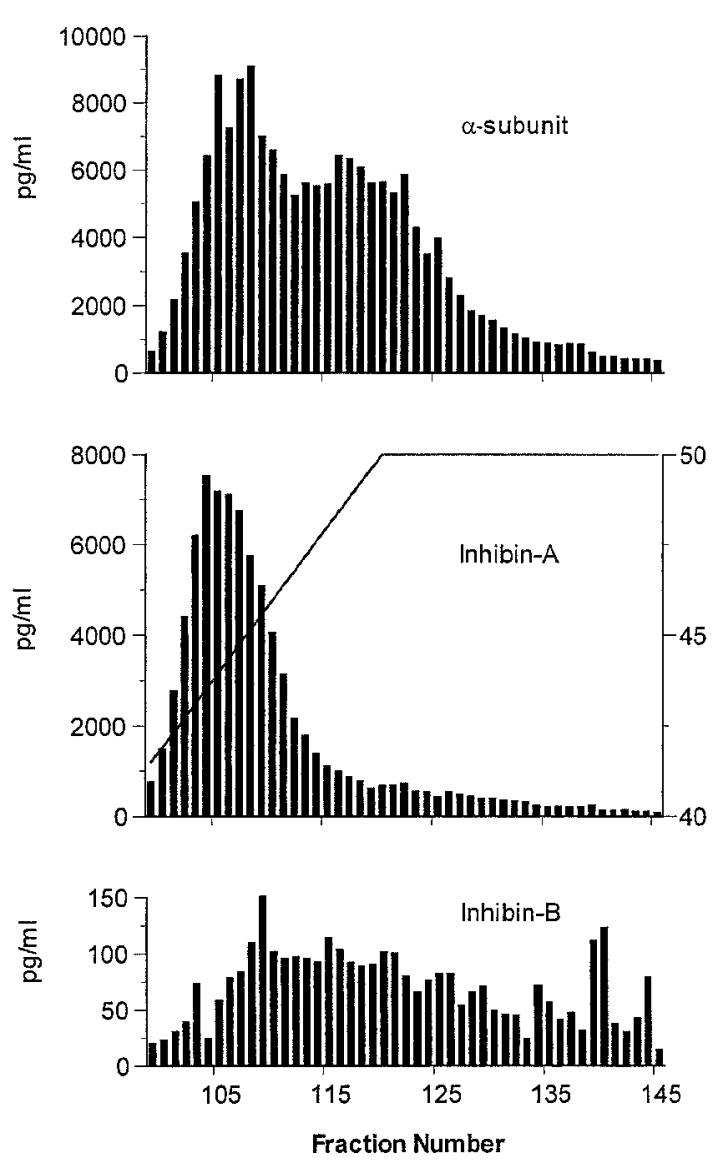

Figure 3 Inhibin RP-HPLC profile of conditioned media (CM-FSH) collected from FSH-stimulated granulosa cell cultures. Inhibin-A and $\alpha$ subunit were measured by IFMA and inhibin-B by ELISA (Groome standard preparation) as described in Materials and Methods. The acetonitrile gradient used for elution is indicated on the inhibin-A panel.

'crossing point'. The standard curve consists of these crossing points defined in terms of cycle number, plotted against the $\log$ concentration of the standard cDNA (Fig. 7B). The size of the $\alpha$ subunit PCR product (306 bp) was confirmed by gel electrophoresis (Fig. 7C) and melting point analysis gave a melting point $\left(91.4{ }^{\circ} \mathrm{C}\right)$ characteristic for this product, with all three dilutions of the standard producing overlapping profiles (Fig. 7D). Similar profiles were collected for each inhibin subunit (data not shown) so that the level of expression of each mRNA could be calculated.

The expression of inhibin $\alpha, \beta_{\mathrm{A}}$ and $\beta_{\mathrm{B}}$ subunit mRNAs was detected in 4-day-old rat ovaries and became maximal in ovaries collected from 8-day-old rats (Fig. 8). Thereafter, the level of mRNA expression of each inhibin subunit declined significantly with $\beta_{\mathrm{A}}$ returning to levels of expression recorded in 4-day-old ovaries, $\beta_{\mathrm{B}}$ levels falling below the level of expression found in day- 4 ovaries
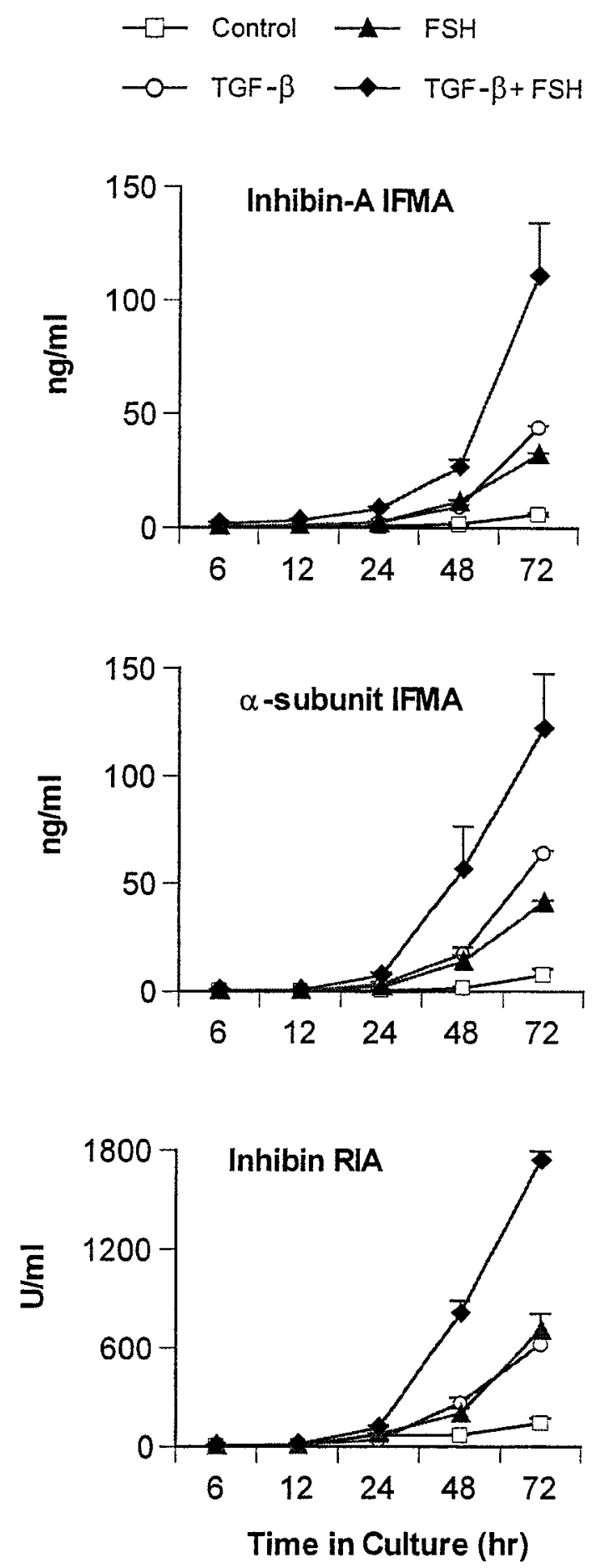

Figure 4 Time-course of production of inhibin-A and $\alpha$ subunit containing inhibin forms (measured by IFMA) and immunoactive inhibin (measured by the Monash RIA) by dispersed ovarian cell cultures prepared from 8-day-old rats, after various treatments. Wells received media alone (control), FSH $(20 \mathrm{ng} / \mathrm{ml}), \mathrm{TGF}-\beta$ $(10 \mathrm{ng} / \mathrm{ml})$, or TGF- $\beta$ plus FSH. Values are means \pm S.E.M., $n=3$ wells/group. The data are representative of three experiments. 

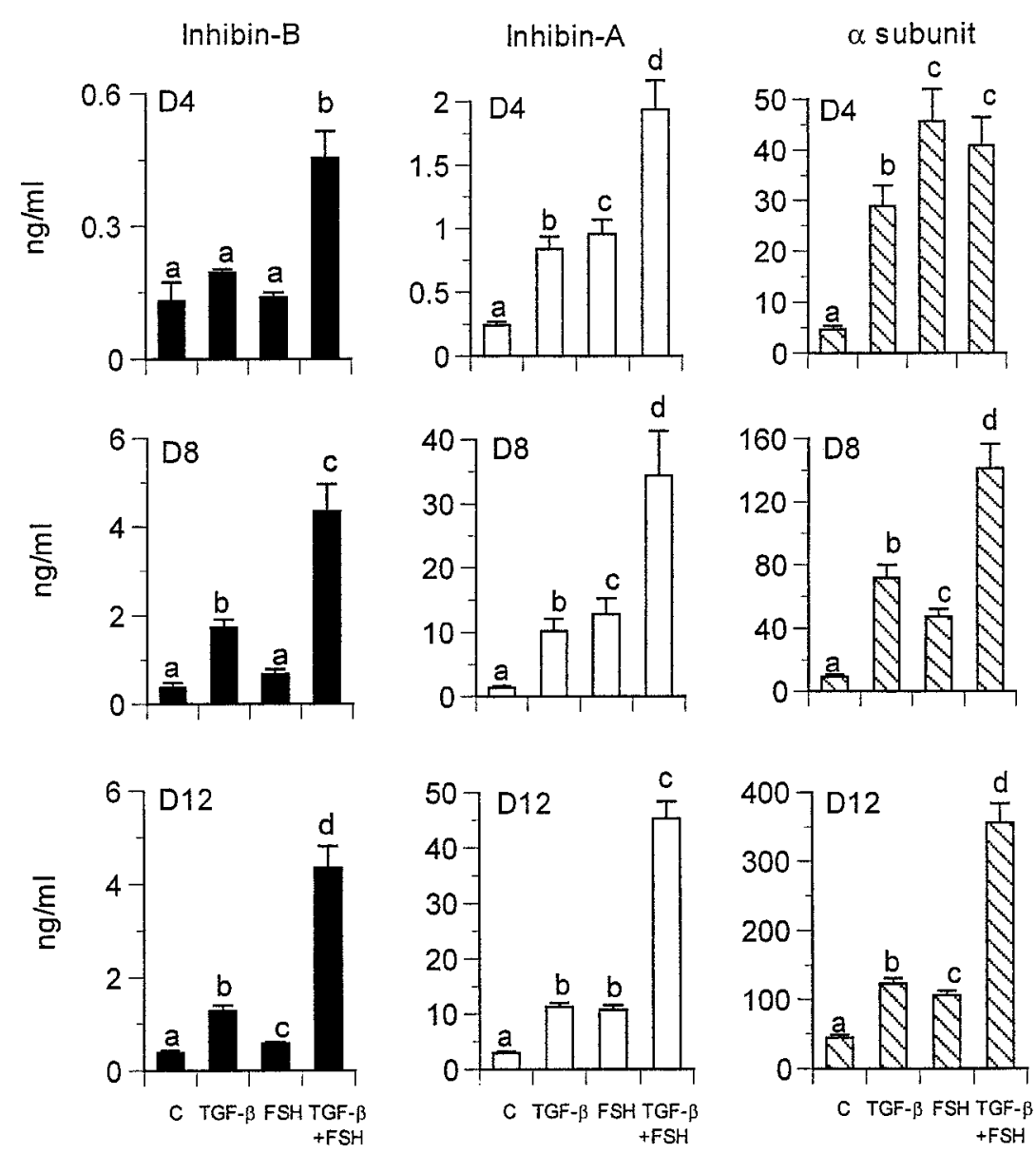

Figure 5 Inhibin-A, $-B$ and $-\alpha$ subunit levels in conditioned media collected from dispersed ovarian cell cultures of 4 (D4)-, 8 (D8)- and 12 (D12)-day-old rats, after various treatments. For inhibin-A and $\alpha$ subunit measurements, conditioned media from each treatment group were serially diluted and compared with the human recombinant $31 \mathrm{k}$ inhibin as standard using parallel-line bioassay statistics. Statistical significance was determined from calculated 95\% confidence limits, the upper 95\% limit being represented as error bars on the figure. Inhibin-B was measured at a single dilution using the ROVE preparation as standard and the data expressed in terms of the Groome inhibin-B standard $(\mathrm{pg} / \mathrm{ml})$. Media alone $(\mathrm{C})$, TGF- $\beta(10 \mathrm{ng} / \mathrm{ml})$ and FSH $(20 \mathrm{ng} / \mathrm{ml})$; combined TGF- $\beta$ and FSH regimens employed doses used for single treatments. Statistical significance is indicated by different letters, $P<0 \cdot 05$. The data are representative of three experiments for inhibin-A and $\alpha$ subunit, while the inhibin-B data are the mean of three experiments.

and $\alpha$ subunit expression reduced but elevated relative to day-4 levels.

To directly compare the levels of expression of each inhibin subunit mRNA in 4-, 8- and 12-day-old ovaries, threshold crossing points (cycle numbers) were analysed (Fig. 9) and fold changes calculated (Table 4). On each of the days observed, there was significantly greater expression of inhibin- $\alpha$ subunit mRNA in the ovaries, as indicated by the reduced number of PCR cycles to attain the threshold crossing point, relative to $\beta_{\mathrm{A}}$ or $\beta_{\mathrm{B}}$ (Fig. 9) and 16-, 32- and 64-fold increases in expression were calculated at day 4, 8 and 12 respectively (Table 4). Similar levels of expression of $\beta_{\mathrm{A}}$ and $\beta_{\mathrm{B}}$ mRNAs at day 4 and 8 were noted, but by day 12 there was two-fold more $\beta_{\mathrm{A}}$ subunit mRNA relative to $\beta_{\mathrm{B}}$ subunit mRNA (Fig. 9 and Table 4).

Expression of inhibin subunit mRNAs by isolated granulosa cell preparations

The three inhibin subunit mRNAs were present in granulosa cells isolated from ovaries of untreated or DES-treated rats (Fig. 10). DES treatment for 4 days 


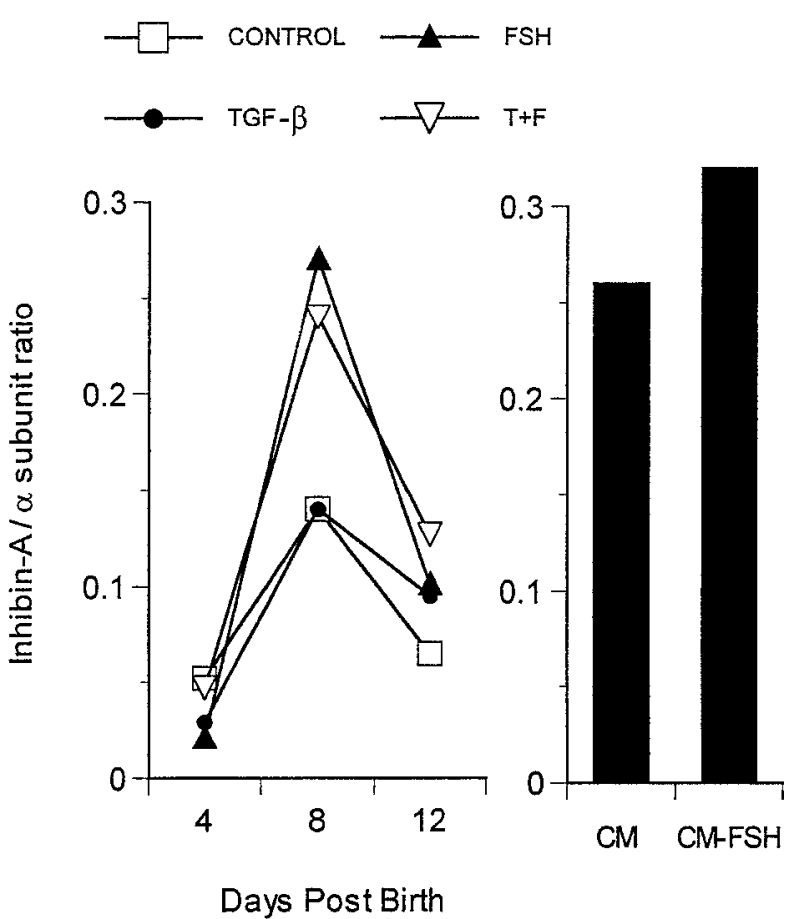

Figure 6 The inhibin-A: $\alpha$ subunit ratio of conditioned media collected from post-natal ovarian cells and granulosa cell cultures prepared from DES-treated, 25-day-old rats. The data presented in Fig. 5 and Table 1 have been replotted to highlight the impact of follicle populations and FSH, TGF- $\beta$ and combined TGF- $\beta+$ FSH $(T+F)$ stimulation on inhibin-A and $\alpha$ subunit production by ovaries or isolated granulosa cells. Granulosa cell-conditioned media from basal (CM) or FSH-stimulated cultures (CM-FSH).

prior to granulosa cell isolation significantly reduced the level of expression of both $\beta$ subunit mRNAs by granulosa cells without changing the expression of inhibin $\alpha$ subunit mRNA compared with control (Fig. 10).

To directly compare the levels of expression of each inhibin subunit mRNA in these granulosa cell preparations, threshold crossing points (cycle numbers) were analysed (Fig. 11) and fold changes calculated (Table 5). In granulosa cell preparations isolated from ovaries of both untreated and DES-treated rats, inhibin $\alpha$ subunit mRNA was expressed at significantly greater levels than either of the $\beta$ subunits, as indicated by the reduced number of cycles required to reach the threshold crossing point (Fig. 11) and the calculated eight-fold difference in mRNA expression (Table 5). There was no difference in the relative levels of expression of $\beta_{\mathrm{A}}$ or $\beta_{\mathrm{B}}$ in granulosa cells from DES-treated or control immature rats.

\section{Discussion}

The significance of individual follicle populations, in relation to dimeric inhibin and free inhibin $\alpha$ subunit
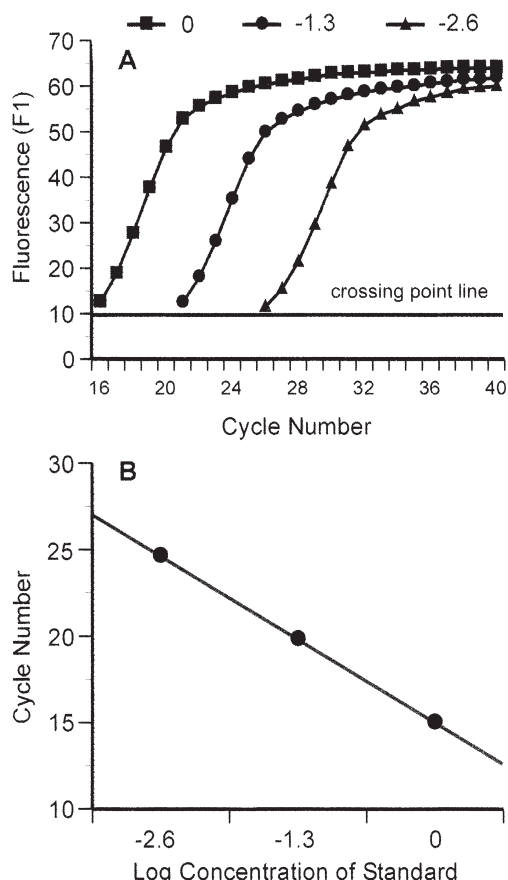

C

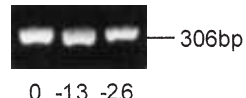

Log concentration of standard

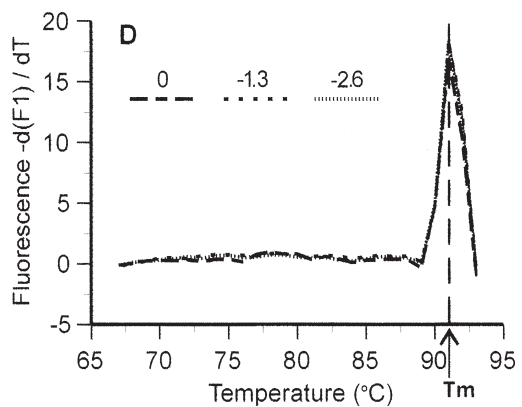

Figure 7 Profiles generated by LightCycler PCR for measuring inhibin $\alpha$ subunit mRNA expression. (A) Fluorescence profiles of the diluted standard cDNA (represented as log concentrations) showing the increase in fluorescence which occurs as the number of PCR cycles increases. (B) Standard curve constructed from three dilutions of the standard ovarian CDNA pool which were subject to 40 cycles of PCR. Log concentrations of the standard are plotted against the threshold crossing point (cycle number) for each dilution. (C) Estimation of PCR product size by agarose gel electrophoresis. (D) Melting curve profiles for the amplified standard cDNA (represented as log concentrations) displayed as first negative derivatives $(-\mathrm{dF} / \mathrm{dT})$. Specific PCR products have characteristic melting points $\left(T_{m}\right)$. The $T_{m}$ for a DNA product is defined as the temperature at which half of the DNA helical structure is lost. For the inhibin- $\alpha$ subunit PCR product the $T_{m}$ was estimated to be $91.4{ }^{\circ} \mathrm{C}$. 


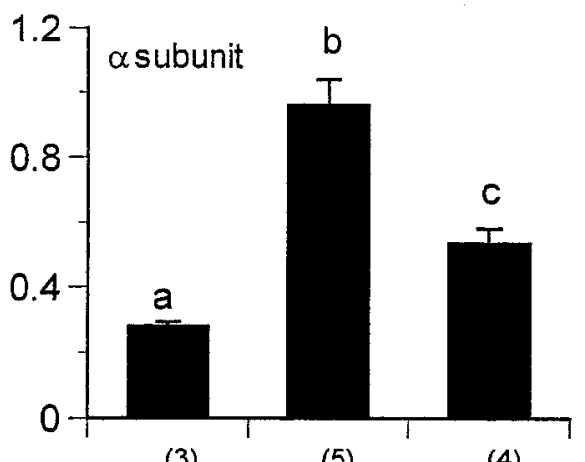

(3)

(5)

(4)

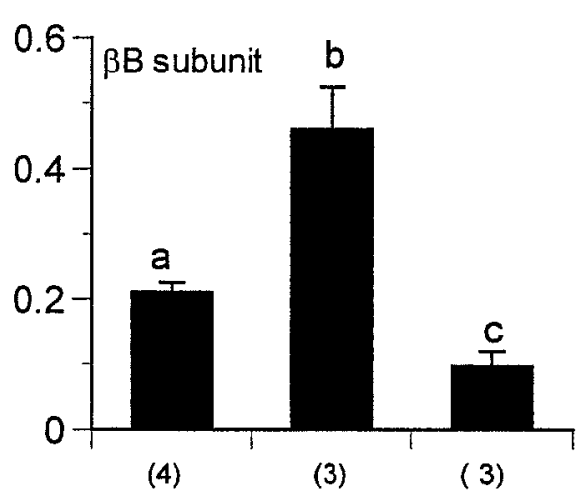

(4)

(3)

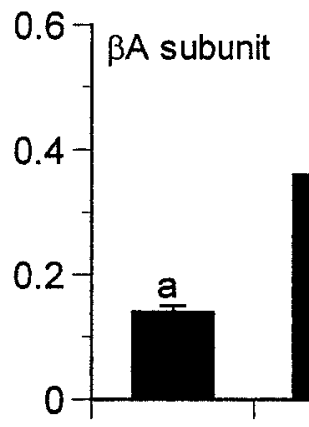

(3)

(3)

(3)

4

8

12

\section{Days Post Birth}

Figure 8 Levels of expression of inhibin subunit mRNAs in post-natal rat ovaries, normalised for GAPDH. The number of pools analysed separately at each age is indicated in parentheses. The data are represented as means \pm S.E.M., with different letters denoting statistical significance $(P<0 \cdot 05)$ within the expressed inhibin subunit.
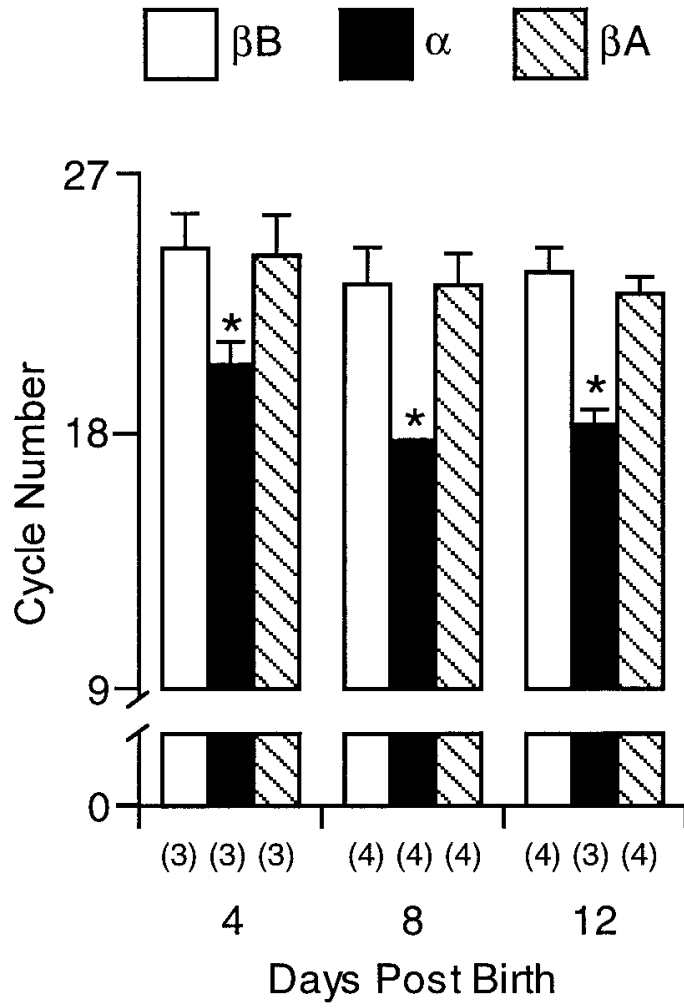

Figure 9 Comparison of threshold crossing points (cycle numbers) for the inhibin subunit mRNAs amplified from ovaries of 4-, 8- and 12-day-old rats. An inverse relationship exists between cycle number and the level of mRNA expression. The number of pools analysed separately at each age is indicated in parentheses. The data are represented as means \pm S.E.M. ${ }^{*} P<0.05$ compared with $\beta$ subunit crossing points.

production and inhibin subunit mRNA expression, has been addressed in these studies using the post-natal rat ovary as a model and specific two-site immunoassays and real time PCR respectively. Characteristic populations of follicles are contained within the ovaries of 4-, 8- and 12-day-old rats (Drummond et al. 1996). Ovaries of 4-day-old rats are composed of primordial and primary

Table 4 Relative levels of expression of inhibin subunit mRNAs by post-natal rat ovaries, expressed as fold changes

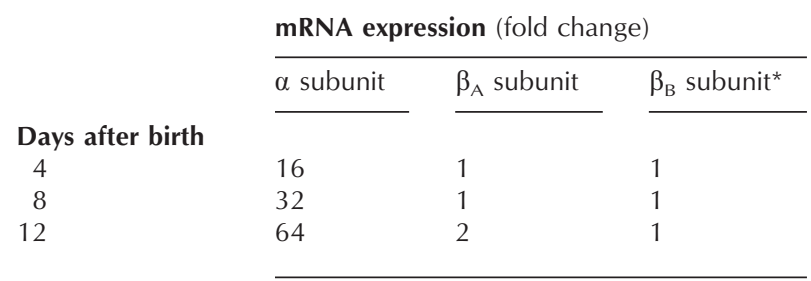

*Fold changes were calculated from crossing point values (Fig. 3) where a difference of one cycle corresponds to a two-fold change in expression. The level of expression was determined relative to the expression of the $\beta_{B}$ subunit, which was arbitrarily assigned a value of 1 on each of the days. 

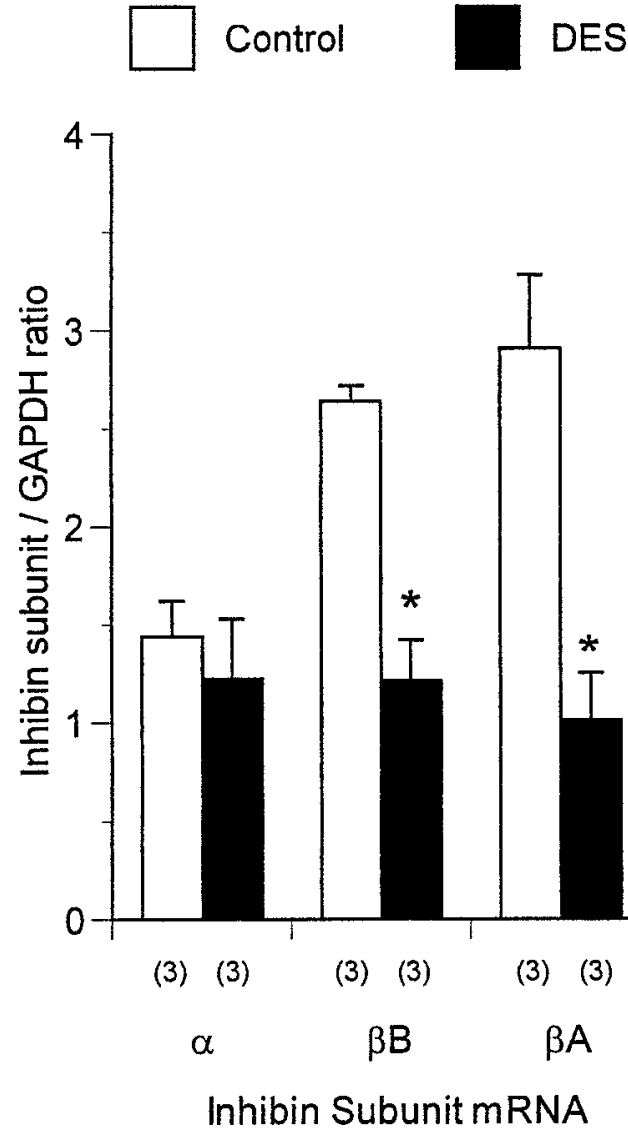

Figure 10 Levels of expression of inhibin subunit mRNAs in granulosa cells isolated from ovaries of untreated or DES-treated (4 days) rats normalised for GAPDH. The number of pools analysed in each treatment group is indicated in parentheses. The data are represented as means \pm S.E.M. ${ }^{*} P<0.05$ relative to the appropriate control.

follicles, whereas day- 8 ovaries contain numerous preantral follicles with multiple layers of granulosa cells and day-12 ovaries contain antral follicles, in addition to their complements of primordial and primary follicles. We have previously measured the levels of immunoactive inhibin by the relatively non-specific Monash RIA, in cultures of post-natal ovarian cells stimulated with activin (Drummond et al. 1996), but it was not possible at that time to ascertain what proportion of measured inhibin could be attributed to free $\alpha$ subunit (and thus biologically inactive inhibin), or dimeric inhibin-A or $-\mathrm{B}$, given that the RIA detected all inhibin forms containing an $\alpha$ subunit. In this study, specific two-site assays for inhibin-A, -B and all $\alpha$ subunit-containing inhibin forms were employed to investigate the inhibin forms present in post-natal ovarian cell-conditioned media and granulosa cell-conditioned media prepared from DES-treated rats. The regulation and temporal production of the inhibins by post-natal ovarian cells was also assessed. In addition, we
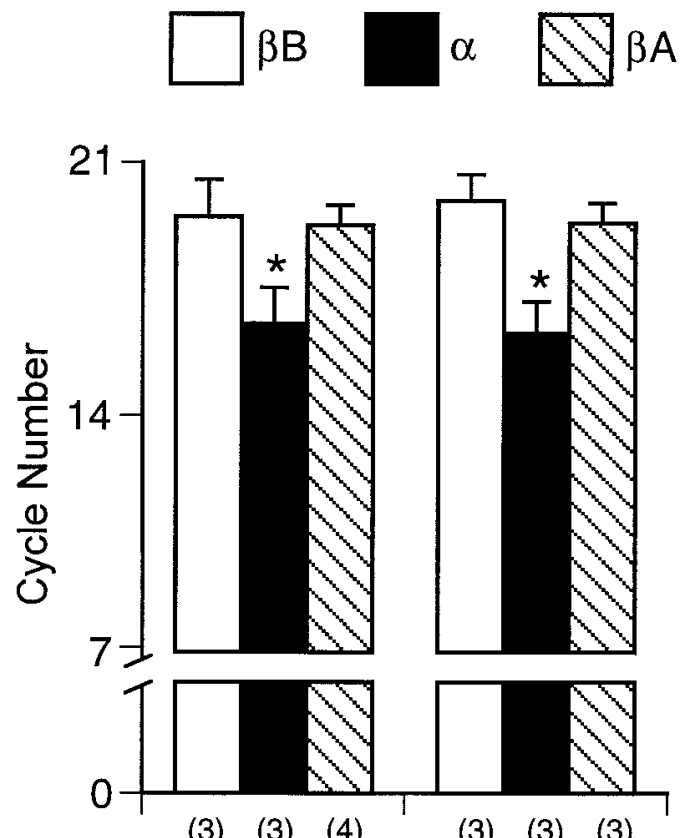

(3) (3) (4)

(3) (3) (3)

\section{Control DES-treated}

Figure 11 Comparison of threshold crossing points (cycle numbers) for the inhibin subunit mRNAs in granulosa cells isolated from the ovaries of untreated or DES-treated (4 days) rats. An inverse relationship exists between cycle number and the level of mRNA expression. The number of pools analysed in each treatment group is indicated in parentheses. The data are represented as means \pm S.E.M. ${ }^{*} P<0 \cdot 05$ compared with $\beta$ subunit crossing points.

estimated the level of expression of each of the inhibin subunit mRNAs by real time PCR. This novel technology offers superior semi-quantitative analysis of gene expression. Real time PCR has a rapid turn-around time for amplification of cDNA (approximately $30 \mathrm{~min} / \mathrm{run}$ ) and does not need procedures such as gel electrophoresis and Southern blots for analysis of PCR products. The technique is highly sensitive and only picogram quantities of

Table 5 Relative levels of expression of inhibin subunit mRNAs by granulosa cells isolated from ovaries of control and DES-treated rats, expressed as fold changes

\begin{tabular}{|c|c|c|c|}
\hline & \multicolumn{3}{|c|}{ mRNA expression (fold change) } \\
\hline & $\alpha$ subunit & $\beta_{\mathrm{A}}$ subunit & $\beta_{\mathrm{B}}$ subunit* $^{*}$ \\
\hline Treatment & & & \\
\hline Control & 8 & 1 & 1 \\
\hline DES & 8 & 1 & 1 \\
\hline
\end{tabular}

${ }^{*}$ Fold changes were calculated from crossing point values (Fig. 5) where a difference of one cycle corresponds to a two-fold change in expression. The level of expression was determined relative to the expression of the $\beta_{\mathrm{B}}$ subunit, which was arbitrarily assigned a value of 1 for each treatment. 
cDNA are required for amplification. It is also possible to directly compare the levels of expression of individual PCR products by analysing crossing point values and calculating fold changes in relation to cycle numbers, given that a difference of one cycle corresponds to a two-fold change in expression, when PCR is performed in the linear range.

All forms of immunoactive inhibin (inhibin-A, -B and $-\alpha$ ) were detected in medium conditioned by post-natal ovarian cells and granulosa cells prepared from DEStreated rats, which is consistent with the finding that follicle populations, primary through to antral, expressed the inhibin subunit mRNAs (Drummond et al. 1996, this study). The levels of $\alpha$ subunit measured in these conditioned media samples were greater than that which could be accounted for in terms of dimeric inhibin-A or $-\mathrm{B}$, indicating that free inhibin $\alpha$ subunit is prominent in the ovary. This observation was confirmed in fractionation of CM-FSH using an HPLC procedure known to separate dimeric inhibin from monomeric inhibin (Risbridger et al. 1989) and by the mRNA analyses which showed that inhibin $\alpha$ subunit mRNA was always more abundant than either $\beta$ subunit. It remains unclear as to why an excess of $\alpha$ subunit is produced by the rat ovary. A large reservoir of $\alpha$ subunit may be necessary to ensure formation of dimeric inhibin, rather than allow dimerisation of the $\beta$ subunits to produce activins. Further studies are required to expand on the kinetics and processing of the inhibin subunits, in combination with measurements of activin. A close correlation of $\alpha$ subunit activity with inhibin-A was noted following HPLC fractionation of conditioned media. Inhibin-A activity was largely responsible for the first peak of $\alpha$ subunit activity, with the second peak of activity most likely due to free forms of the $\alpha$ subunit, given that inhibin-B does not seem to contribute significantly to the $\alpha$ subunit content of the conditioned media pool. These data showed that the levels of inhibin-A and $\alpha$ subunit could be directly compared, which is perhaps not surprising given that the assays share a common standard and coating antibody. Gel filtration confirmed previously published observations (Bicsak et al. 1988, LaPolt et al. 1989) that the predominant inhibin forms in FSH-stimulated granulosa cell-conditioned media are $31 \mathrm{k}$ inhibin and molecular weight forms of the $\alpha$ subunit greater than $31 \mathrm{k}$. However, unlike Bicsak et al. (1988), we were able to detect $31 \mathrm{k}$ inhibin in basal granulosa cell-conditioned media (data not shown). This difference probably reflects the different methodologies employed and their relative sensitivities. Our data suggest that the predominant form of dimeric inhibin produced by cultures of FSHstimulated granulosa cells prepared from DES-treated, 25-day-old rats is inhibin-A. Our results are consistent with Lanuza et al. (1999) who reported that FSHstimulated granulosa cell cultures prepared from DEStreated immature rats produced fivefold more inhibin-A than inhibin-B and basal cultures produced 10- to 15-fold more inhibin-A than inhibin-B. Inhibin-B, while detectable across gel filtration and HPLC profiles, was without any clear elution pattern and did not appear to contribute substantially to total inhibin production by these differentiated granulosa cells. Furthermore, given that the crossreactivity of inhibin-A in the inhibin-B ELISA is estimated at 0.5\% (Groome et al. 1996), it is quite likely that some of the activity measured in these fractions was due to the presence of inhibin-A and not directly due to inhibin-B.

The actual levels of the inhibin forms reported here may be underestimated as Woodruff et al. (1996) suggest, given that the $\alpha$ subunit of the human and rat differ in amino acids 1-32. The degree of underestimation is dependent on the extent to which human and rat inhibins cross-react in the assay. Simply put, rat inhibins are likely to have a reduced affinity for antibody reagents based on the human sequence, which is clearly a problem for laboratories undertaking inhibin measurements in biological fluids of non-human species, since most of the new generation assays employ human assay standards and antibodies directed at the human $\alpha$ subunit. It was evident from the high between-assay variation that we calculated for the inhibin-B ELISA that the human standard used in this assay was not appropriate for the measurement of rat inhibin-B in conditioned media. The extensive washing of the plates, which was required to maintain low background, was detrimental to the binding of rat inhibin-B to the human-based antibody reagents. Quite simply, rat samples and the human standard behaved differently under the defined assay conditions, hence our utilization of a rat ovarian extract (ROVE) as standard for the measurements of inhibin-B in conditioned media from post-natal ovarian cell cultures. Nevertheless, the pattern of secretion of inhibin-B by post-natal ovarian cells was reproducible whatever standard was employed. It will, however, require suitable purified rat standard preparations to become available for the absolute levels of all the inhibin forms to be determined.

The capacity of the ovary to produce dimeric inhibin-A, -B and $-\alpha$ subunit (IFMA and Monash RIA), in general, increased with age and follicular development. All inhibin forms were detected in basal cultures of dispersed ovarian cells, indicating that even the smallest follicles, most likely primary follicles, are capable of producing inhibin. The results are consistent with our data on the expression of the mRNA and protein for the inhibin $\alpha, \beta_{\mathrm{A}}$ and $\beta_{\mathrm{B}}$ subunits in the ovary during post-natal development (Drummond et al. 1996, this study). Primordial and primary follicles of 4-day-old ovaries responded differentially to FSH and TGF- $\beta$ in terms of the inhibin forms, with inhibin-A and $\alpha$ subunit levels enhanced but inhibin-B levels unchanged from basal. The most dramatic change occurred between days 4 and 8 when notable increases in inhibin levels occurred, particularly in inhibin-A and $\alpha$ subunit, indicating that the 
proliferation of granulosa cells and the appearance of preantral/secondary follicles is a defining point in ovarian inhibin production. Consistent with these results, an increase in the expression of all of the inhibin subunits was observed in the ovaries of 8-day-old rats. Changes in the sensitivity of these follicles to FSH was highlighted by calculation of an inhibin-A: $\alpha$ subunit ratio, which showed that more inhibin-A was produced relative to $\alpha$ subunit in response to FSH at day 8 than day 4. This finding also implies an increased capacity of preantral follicles to produce $\beta_{\mathrm{A}}$ subunits and thus the potential for an increase in activin-A production exists. The appearance of antral follicles in the ovaries of 12-day-old rats signalled a fall in the inhibin-A: $\alpha$ subunit ratio which could be attributed to either an increase in $\alpha$ subunit production by the ovary or a decline in $\beta_{\mathrm{A}}$ subunit production. We noted that $\beta$ subunit mRNA expression declined with the appearance of antral follicles at day 12. It was also interesting to note that preantral follicles did not produce inhibin-B in response to FSH alone but, in combination with TGF- $\beta$, inhibin-B levels were significantly enhanced. In the absence of calibrated standard preparations we cannot directly compare the levels of inhibin-A and inhibin-B. We have, however, presented data which allow us to hypothesise that both dimeric inhibin forms are produced by the post-natal rat ovary (cell culture data) and, after day 4 , are equally responsive to stimulation, but that at some point during development inhibin-A production increases relative to inhibin-B and inhibin-A becomes the predominant form (gel filtration and HPLC data) in the ovary. Our hypothesis is further supported by the decline in expression of $\beta_{\mathrm{B}}$ relative to $\beta_{\mathrm{A}}$ mRNA, which was observed in the ovaries of 12-day-old rats. The actual levels of TGF- $\beta$ and FSH and the presence and concentration of their specific receptors within individual follicles during development will be important for establishing how follicles respond in terms of dimeric inhibin production. Our preliminary studies investigating dimeric inhibin production in response to activin (A E Drummond \& J K Findlay, unpublished observations) using the two-site immunoassays described above, indicate that, in combination with $\mathrm{FSH}$, activin stimulated production of the inhibin forms beyond that elicited by the individual factors or the combined regimen of TGF- $\beta$ and FSH, in post-natal ovarian cell cultures. Issues related to redundancy or indeed specific roles for activin and TGF- $\beta$ in the ovary are speculative at best, in the absence of data estimating the intraovarian levels of these local regulators and the presence of their respective receptor/signal transduction systems.

The role of oestrogen in mediating inhibin production also requires consideration. The formation of the theca and the availability of androgen as substrate facilitates oestrogen production, which becomes significant in the ovary for the first time around day 10 (Carson \& Smith 1986). This increase in oestrogen levels in vivo, may explain the decrease in $\beta_{\mathrm{A}}$ and $\beta_{\mathrm{B}}$ mRNA expression observed in ovaries of 12-day-old rats. This hypothesis was supported by our finding that DES treatment of immature rats down-regulated the expression of $\beta_{\mathrm{A}}$ and $\beta_{\mathrm{B}}$ subunit mRNA in granulosa cells, in the absence of any change in $\alpha$ subunit expression. In contrast, Turner et al. (1989) using Northern blot analysis, reported that inhibin $\alpha$ and $\beta_{\mathrm{A}}$ mRNA expression was increased by oestradiol treatment whereas $\beta_{\mathrm{B}}$ mRNA expression was uneffected. These granulosa cells were also isolated from DES-primed immature rats, but they were cultured in vitro for $48 \mathrm{~h}$ in the presence of oestradiol prior to the extraction of RNA. The absence of other endogenous regulators of inhibin subunit expression, perhaps those of thecal origin, in the in vitro environment may account for the differences observed between these studies. The impact of oestradiol treatment on inhibin subunit mRNA expression was also investigated by Aloi et al. (1995) using dot blot hybridisation. They found that a single injection of oestradiol to hypophysectomised rats led to increased expression of $\alpha$ subunit but no change in the expression of either $\beta$ subunit by the ovary, $24 \mathrm{~h}$ after administration. The absence of gonadotrophins and the transient exposure to oestradiol employed in this model may have contributed to the findings of this report.

The 'altered' state of granulosa cells isolated from the ovaries of DES-treated immature rats has been highlighted in these and other reports (Drummond et al. 1999). A recent study investigating the expression of oestrogen receptors $(\mathrm{ER} \alpha$ and $\mathrm{ER} \beta$ ) in the ovary, reported that ER mRNAs were down-regulated in granulosa cells isolated from rat ovaries after DES treatment (Drummond et al. 1999). Thus, researchers applying this model to studies of ovarian function, particularly those with an interest in inhibin/activin production or expression, should be aware that inhibin $\beta$ subunit expression is suppressed in these granulosa preparations. Additional studies are required to establish whether this suppression is reversed in culture.

In summary, it has been shown that (a) post-natal rat ovaries and isolated granulosa cells express all three inhibin subunit mRNAs. (b) Cultures of dispersed post-natal ovaries and granulosa cells produced inhibin-A, inhibin-B and $-\alpha$ subunit. (c) $\alpha$ subunit production generally exceeded that of both dimeric inhibins and was reflected in the increased expression of $\alpha$ subunit mRNA relative to $\beta$ subunit mRNAs. (d) Both inhibin-A and inhibin-B were produced by day-4 post-natal ovaries containing only primordial and primary follicles but, with the appearance of secondary and antral follicles, inhibin-A production increased relative to that of inhibin-B. (e) The decline in inhibin subunit expression by the post-natal ovary may be explained in part by the production of oestrogen in situ by maturing follicles. (f) FSH and TGF- $\beta$ plus FSH promoted dimeric inhibin-A production by day- 8 post-natal ovaries which contain only primordial, primary and secondary preantral follicles, whereas TGF- $\beta$ alone did not 
alter the ratio of inhibin-A to $\alpha$ subunit from that of controls. It is concluded that the profile of dimeric inhibin production by rat granulosa cells changes during folliculogenesis and that inhibin-A is the form produced by the differentiated ovary. Further definition of these profiles will require the availability of rat standards for each of the inhibins.

\section{Acknowledgements}

The financial support of the National Health and Medical Research Council of Australia (Program Grant Regkey No. 983212) is gratefully acknowledged. The authors would like to thank Dr A Mason for the activin-A preparation, Biotech Australia for the inhibin fusion proteins and human recombinant inhibin preparation, Dr J Mather for the inhibin-B preparation, NIBSC (Potters Bar, Herts, UK) for the 91/624 inhibin-A standard, Karen Fitzsimmons for technical assistance and Sue Panckridge for help in the preparation of the figures.

\section{References}

Albano RM, Groome N \& Smith JC 1993 Activins are expressed in preimplantation mouse embryos and in ES and EC cells and are regulated on their differentiation. Development 117 711-723.

Aloi JA, Dalkin AC, Schwartz NB, Yasin M, Mann DJ, Haisenleder DJ \& Marshall JC 1995 Ovarian inhibin subunit gene expression: regulation by gonadotrophins and oestradiol. Endocrinology 136 $1227-1232$

Bicsak TA, Tucker EM, Cappel S, Vaughan J, Rivier J, Vale W \& Hsueh AJW 1986 Hormonal regulation of granulosa cell biosynthesis. Endocrinology 119 2711-2719.

Bicsak TA, Cajander SB, Vale W \& Hsueh AJW 1988 Inhibin: studies of stored and secreted forms by biosynthetic labeling and immunodetection in cultured rat granulosa cells. Endocrinology 122 741-748.

Burger HG 1993 Evidence for a negative feedback role of inhibin in follicle stimulating hormone regulation in women. Human Reproduction 8 129-132.

Carson R \& Smith J 1986 Development and steroidogenic activity of preantral follicles in the neonatal rat ovary. Journal of Endocrinology $11087-92$.

Chomczynski P \& Sacchi N 1987 Single-step method of RNA isolation by acid guanidinium thiocyanate-phenol-chloroform extraction. Analytical Biochemistry 162 156-159.

Draper LB, Matzuk MM, Roberts VJ, Cox E, Weiss J, Mather JP \& Woodruff TK 1998 Identification of an inhibin receptor in gonadal tumors from inhibin alpha-subunit knockout mice. Journal of Biological Chemistry 273 398-403.

Drummond AE, Dyson M, Mercer JE \& Findlay JK 1996 Differential responses of post-natal rat ovarian cells to FSH and activin. Molecular and Cellular Endocrinology 122 21-32.

Drummond AE, Baillie AJ \& Findlay JK 1999 Ovarian estrogen receptor $\alpha$ and $\beta$ mRNA expression: impact of development and estrogen. Molecular and Cellular Endocrinology 149 153-161.

Dunkel L, Tilly JL, Shikone T, Nishimori K \& Hsueh AJ 1994 Follicle-stimulating hormone receptor expression in the rat ovary: increases during prepubertal development and regulation by the opposing actions of transforming growth factors beta and alpha. Biology of Reproduction $\mathbf{5 0}$ 940-948.
Erickson GF \& Hsueh AJW 1978 Secretion of 'inhibin' by rat granulosa cells. Endocrinology 103 1960-1963.

Finney DJ 1964 Statistical Methods in Biological Assay, edn 2. London: Charles Griffin.

Forage RG, Brown RW, Ring JM, Stewart AG, Milborrow HM, Oliver KL, Atrache BT, Devine PL, Hudson GC, Goss NH, Tolstochev P, Robertson DM, Doughton B, de Kretser DM, Burger HG \& Findlay JK 1987 The cloning and expression of inhibin genes: $\alpha$ subunit use as a fecundity vaccine. In Inhibin: Non-Steroidal Regulation of Follicle Stimulating Hormone Secretion. Serono Symposium, vol. 42, pp 89-103. Eds HG Burger, DM de Kretser, JK Findlay \& M Igarashi. New York: Raven Press.

Groome N 1991 Ultrasensitive two-site assays for inhibin-A and activin-A using monoclonal antibodies raised to synthetic peptides. Journal of Immunological Methods 145 65-69.

Groome NP, Illingworth PJ, O'Brien M, Pai R, Rodger FE, Mather JP \& McNeilly AS 1996 Measurement of dimeric inhibin B throughout the human menstrual cycle. Journal of Clinical Endocrinology and Metabolism 81 1401-1405.

Hillier SG, Yong EL, Illingworth PJ, Baird DT, Schwall RH \& Mason AJ 1991 Effect of recombinant inhibin on androgen synthesis in cultured human thecal cells. Molecular and Cellular Endocrinology 75 R1-R6.

Jih MH, Lu JK, Wan YJ \& Wu TC 1993 Inhibin subunit gene expression and distribution in the ovaries of immature, young adult, middle-aged and old female rats. Endocrinology 132 319-326.

Knecht M, Feng P \& Catt K 1987 Bifunctional role of transforming growth factor-beta during granulosa cell development. Endocrinology $1201243-1249$.

Lanuza GM, Groome NP, Baranao JL \& Campo S 1999 Dimeric inhibin $\mathrm{A}$ and $\mathrm{B}$ production are differentially regulated by hormones and local factors in rat granulosa cells. Endocrinology 140 2549-2554.

LaPolt PS, Soto D, Su J-G, Campen CA, Vaughan J, Vale W \& Hsueh AJW 1989 Activin stimulation of inhibin secretion and messenger RNA levels in cultured granulosa cells. Molecular Endocrinology 3 1666-1673.

Lowik CWGM, Alblas MJ, van de Ruit M, Papapoulos SE \& van der Pluijm G 1993 Quantification of adherent and nonadherent cells cultured in 96-well plates using the supravital stain neutral red. Analytical Biochemistry 213 426-433.

McLachlan RI, Robertson DM, de Kretser D \& Burger HG 1987 Inhibin - a non-steroidal regulator of pituitary follicle stimulating hormone. Baillieres Clinical Endocrinology and Metabolism 1 89-112.

Magoffin DA \& Jakimiuk AJ 1997 Inhibin A, inhibin B and activin A in the follicular fluid of regularly cycling women. Human Reproduction 12 1714-1719.

Meunier H, Cajander SB, Roberts VJ, Rivier C, Sawchenko P, Hsueh AJW \& Vale W 1988 Rapid changes in the expression of inhibin $\alpha-, \beta \mathrm{A}$ and $\beta \mathrm{B}$ subunits in ovarian cell types during the rat estrous cycle. Molecular Endocrinology 2 1352-1363.

Risbridger GP, Hancock A, Robertson DM, Hodgson Y \& de Kretser DM 1989 Follitropin (FSH) stimulation of inhibin biological and immunological activities by seminiferous tubules and Sertoli cell cultures from immature rats. Molecular and Cellular Endocrinology 67 $1-9$.

Robertson DM, Hayward S, Irby D, Jacobsen J, Clarke L, McLachlan RI \& de Kretser DM 1988 Radioimmunoassay of rat serum inhibin: changes after PMSG stimulation and gonadectomy. Molecular and Cellular Endocrinology 58 1-8.

Robertson DM, Cahir N, Findlay JK, Burger HG \& Groome N 1997 The biological and immunological characterization of inhibin A and $\mathrm{B}$ forms in human follicular fluid and plasma. Journal of Clinical Endocrinology and Metabolism 82 889-896.

Robertson DM, Cahir N, Burger HG, Mamers P, McCloud PI, Pettersson K \& McGuckin M 1999 Combined inhibin and CA125 assays in the detection of ovarian cancer. Clinical Chemistry $\mathbf{4 5}$ 651-658. 
Smyth CD, Gosden RG, McNeilly AS \& Hillier SG 1994 Effect of inhibin immunoneutralisation on steroidogenesis in rat ovarian follicles in vitro. Journal of Endocrinology 140 437-443.

Suzuki T, Miyamoto K, Hasegawa Y, Abe Y, Ui M, Ibuki Y \& Igarashi M 1987 Regulation of inhibin production by rat granulosa cells. Molecular and Cellular Endocrinology 54 185-195.

Tso JY, Sun X-H, Kao T-H, Reece KS \& Wu R 1985 Isolation and characterisation of rat and human glyceraldehyde-3-phosphate dehydrogenase cDNAs: genomic complexity and molecular evolution of the gene. Nucleic Acids Research 13 2485-2502.

Turner IM, Saunders PT, Shimasaki S \& Hillier SG 1989 Regulation of inhibin subunit gene expresssion by FSH and estradiol in cultured rat granulosa cells. Endocrinology 125 2790-2792.

Woodruff TK, Meunier H, Jones PBC, Hsueh AJW \& Mayo KE 1987 Rat inhibin: molecular cloning of alpha- and beta-subunit complementary deoxyribonucleic acids and expression in the ovary. Molecular Endocrinology 1 561-568.

Woodruff TK, D’Agostino J, Schwartz NB \& Mayo KE 1988 Dynamic changes in messenger RNAs in rat ovarian follicles during the reproductive cycle. Science 239 1296-1299.
Woodruff TK, Lyon RJ, Hansen SE, Rice GC \& Mather JP 1990 Inhibin and activin locally regulate rat ovarian folliculogenesis. Endocrinology 127 3196-3205.

Woodruff TK, Besecke LM, Groome N, Draper LB, Schwartz NB \& Weiss J 1996 Inhibin A and inhibin B are inversely correlated to follicle-stimulating hormone, yet are discordant during the follicular phase of the rat estrous cycle, and inhibin A is expressed in a sexually dimorphic manner. Endocrinology 137 5463-5467.

Xiao S, Findlay JK \& Robertson DM 1990 The effect of bovine activin and follicle-stimulating hormone (FSH) suppressing protein/follistatin on FSH induced differentiation of rat granulosa cells in vitro. Molecular and Cellular Endocrinology $691-8$.

Zhang ZW, Findlay JK, Carson RS, Herington AC \& Burger HG 1988 Transforming growth factor beta enhances basal and FSHstimulated inhibin production by rat granulosa cells in vitro. Molecular and Cellular Endocrinology 58 161-166.

Received 24 December 1999

Accepted 18 April 2000 